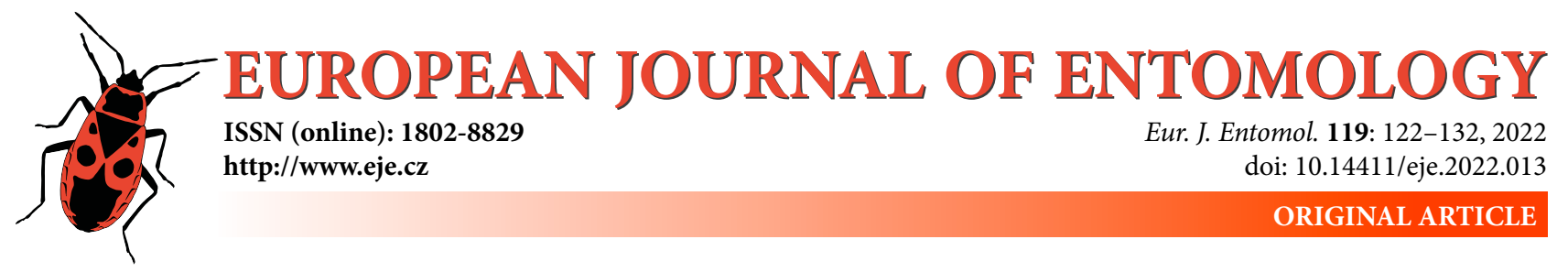

\title{
Indirect interactions between a native and a supposedly non-native wasp species (Hymenoptera: Vespidae: Eumeninae: Anterhynchium)
}

\author{
MISAKI TSUJII ${ }^{1}$ D, ToMOJI ENDO ${ }^{2}$, YUKI MATSUI ${ }^{3}$ and SHINJI SUGIURA ${ }^{1}$ iD \\ ${ }^{1}$ Graduate School of Agricultural Science, Kobe University, Rokkodai, Nada, Kobe 657-8501, Japan; \\ e-mails: tsujii.eumenid9@gmail.com, sugiura.shinji@gmail.com \\ ${ }^{2}$ School of Human Sciences, Kobe College, Okadayama, Nishinomiya 662-8505, Japan; e-mail: endo@mail.kobe-c.ac.jp \\ ${ }^{3}$ The United Graduate School of Agricultural Sciences, Tottori University, Koyama-Minami, Tottori 680-8553, Japan; \\ e-mail: mothya22@gmail.com
}

Key words. Alien species, apparent competition, indirect effects, natural enemies, prey use, resource competition, trap nests

\begin{abstract}
Non-native species pose a threat to native organisms. When non-native and native species are closely related, the former can often competitively exclude the latter. Many studies have focused on competitive exclusion of native insect species by non-native eusocial hymenopterans, including ants, hornets, paper wasps and bees. Although solitary species of wasps have been introduced in many regions, few studies have investigated the effects of these insects on their native congeners. We investigated competitive interactions between native and non-native solitary wasps belonging to the same genus (Hymenoptera: Vespidae: Eumeninae: Anterhynchium). Specifically, we compared resource use and natural enemies of the native Anterhynchium flavomarginatum and supposedly non-native A. gibbifrons at a forest edge in Takasago, Hyogo, Japan, in June-October 2019, using trap nests (bamboo canes). Of 950 bamboo canes, $70(7.4 \%)$ and $50(5.3 \%)$ were used as nests by $A$. flavomarginatum and $A$. gibbifrons, respectively. Anterhynchium flavomarginatum produced two generations over the period studied, whereas $A$. gibbifrons produced only one. Although $A$. gibbifrons began nesting two weeks after $A$. flavomarginatum, the nesting period of $A$. gibbifrons overlapped that of the first nesting period of $A$. flavomarginatum. Nest architecture and the inner diameter of the canes used by both species were similar, suggesting potential competition for nesting resources. Anterhynchium flavomarginatum used larvae of 14 species of moths (Lepidoptera: Crambidae, Pyralidae, Tortricidae) as food for their larval offspring, whereas A. gibbifrons used only a single species, Demobotys pervulgalis (Lepidoptera: Crambidae). Prey species were exclusive to each wasp species, indicating no competition for this resource. Three parasitoid species, Macrosiagon nasutum (Coleoptera: Ripiphoridae), Amobia distorta (Diptera: Sarcophagidae) and Megaselia sp. (Diptera: Phoridae), attacked both Anterhynchium species. The percentage parasitism by Amobia distorta was higher for the native A. flavomarginatum. Anterhynchium gibbifrons may indirectly affect $A$. flavomarginatum via shared parasitoids.
\end{abstract}

\section{INTRODUCTION}

Non-native species can negatively affect native species by both direct and indirect pathways (Elton, 1958; Mack et al., 2000; Sugiura, 2016; David et al., 2017). Direct interactions include consumption and interference (Snyder \& Evans, 2006; Sugiura, 2010, 2016) and indirect interactions are mediated through shared resources, i.e. food or space (Thomson, 2004; Snyder \& Evans, 2006) and enemies (predators, parasitoids and pathogens; Holt \& Bonsall, 2017). When combined, these interactions can lead to the exclusion and displacement of native species (Reitz \& Trumble, 2002; Gao \& Reitz, 2017). When non-native and native species are closely related, the former can competitively exclude or displace the latter, given that congeners are more likely to share resource needs and natural enemies (Reitz \& Trumble, 2002).
The negative effects of non-native insect species on native species and biota are widely reported (Snyder \& Evans, 2006; Kenis et al., 2009). In a review of 403 research publications focused on the ecological effects of invasive insects, $55 \%$ focused on non-native eusocial hymenopterans such as ants, hornets, paper wasps, bumblebees and honeybees (Kenis et al., 2009). Although solitary wasps are more diverse than eusocial wasps (Aguiar et al., 2013; Peters et al., 2017), few studies have focused on non-native solitary wasps, excluding parasitoid species (Kenis et al., 2009). Although some solitary species of wasps have been introduced in many areas (Beggs et al., 2011; Fateryga et al., 2014; Ravoet et al., 2017), Beggs et al. (2011) suggest that their ecological effects may be overlooked because they are of less concern for human health. However, native solitary wasps play a crucial ecological role in controlling herbivorous insects (Losey \& Vaughan, 2006; Tylianakis 
et al., 2007; Brock et al., 2021) and non-native species can threaten both their populations and the ecosystem services they provide. Clarifying the potential effects of non-native solitary wasp introductions improves our understanding of the wider pattern of ecological effects of non-native hymenopterans on native biota.

We aimed to understand the resource use and natural enemies of two solitary wasp congeners (Hymenoptera: Vespidae: Eumeninae: Anterhynchium). In central Japan, Anterhynchium flavomarginatum (Smith, 1852) is commonly found in agricultural fields, secondary forests and urban areas (Iwata, 1975). The congener Anterhynchium gibbifrons Yamane \& Murota, 2015 was recently described on the basis of specimens obtained from Fukui Prefecture, also located in central Japan (Yamane \& Murota, 2015). Several lines of evidence indicate that $A$. gibbifrons has only recently invaded Japan (Watanabe et al., 2020) and is thus considered here as a non-native species (see the subsection 'Species studied' in the Materials and Methods). Wasps in the genus Anterhynchium de Saussure, 1863 nest in pre-existing cavities in wood and bamboo canes (Iwata, 1975; Endo, 2017). Anterhynchium gibbifrons frequently occurs in the same habitat as A. flavomarginatum in central Japan (Yamane \& Murota, 2015; Endo, 2017). If A. gibbifrons shares resource needs and natural enemies with $A$. flavomarginatum, it may outcompete A. flavomarginatum via direct or indirect competition, but these relationships have never been investigated.

To understand the interactions between these two species, we used trap nests to compare resource use and natural enemies under field conditions in Hyogo Prefecture, Japan. Trap nests are artificial nesting resources (e.g., bamboo canes) set out by researchers for solitary bees and wasps that nest in cavities (Fig. 1), which are appropriate for investigating their life histories, prey resources and parasitoids (Krombein, 1967; Staab et al., 2018). This approach is well suited to these congeners given their abundance and known use of trap nests in Hyogo Prefecture (Endo, 2017). We aimed to determine whether these congeners share nest and prey resources and parasitoid species.

\section{MATERIALS AND METHODS}

\section{Study site}

The study sites were located in Kitaike, Amida-cho, Takasago, Hyogo, Japan $\left(34^{\circ} 47^{\prime} \mathrm{N}, 134^{\circ} 47^{\prime} \mathrm{E}\right.$, above sea level 15-20 m) and monitored in June-October 2019 (Tsujii, 2020). Average monthly temperature ranged from 19.6 to $28.1^{\circ} \mathrm{C}$, average monthly humidity ranged from 74 to $83 \%$, and total precipitation was 717 $\mathrm{mm}$ during the period studied (Himeji Meteorological Station; $34^{\circ} 50^{\prime} \mathrm{N}, 134^{\circ} 40^{\prime} \mathrm{E}$, above sea level $38.2 \mathrm{~m}$ ). The study site included paddy fields and secondary forest and the surveys were carried out along a 700-m-long forest edge. The secondary forest was dominated by oaks (e.g., Quercus variabilis Blume and Q. glauca Thunb.) and bamboos [Phyllostachys edulis (Carrière) Houz. and P. nigra (Lodd. ex Loud.) Munro var. henonis (Mitford) Stapf ex Rendle].

\section{Species studied}

Three species of Anterhynchium: A. flavomarginatum, A. melanopterum Yamane, 1981 and A. gibbifrons, are recorded in

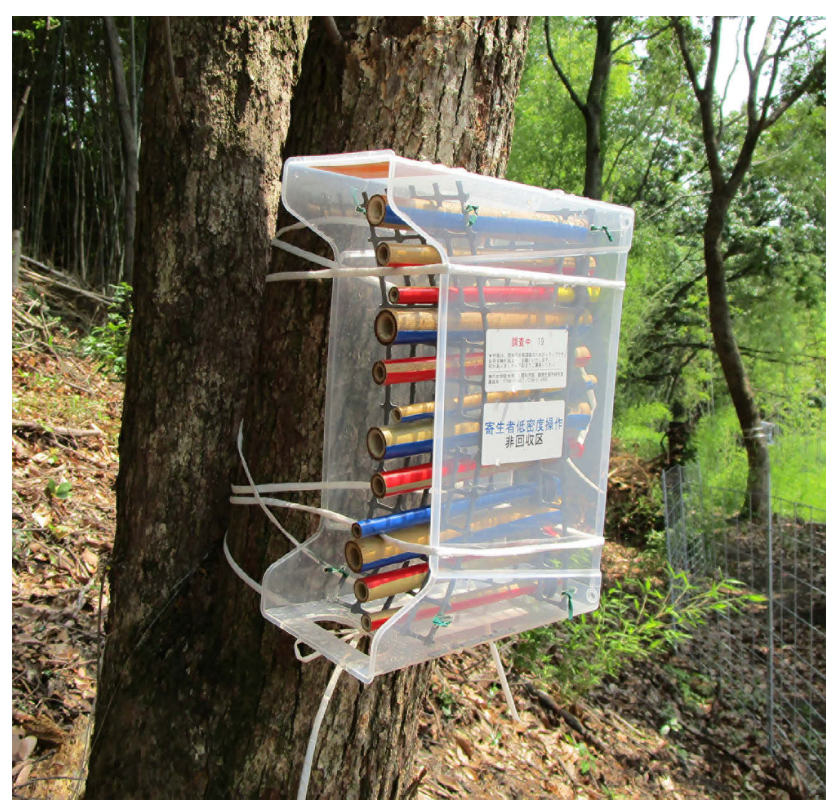

Fig. 1. Trap nests used to study two species of Anterhynchium in central Japan. Each trap box contained 12 bamboo canes.

Japan (Yamane, 1990; Yamane \& Murota, 2015). Anterhynchium flavomarginatum is the most abundant of the three and also occurs throughout East and Southeast Asia (Yamane, 1990; Yamane \& Terayama, 2016). Anterhynchium flavomarginatum has been frequently collected in our study area (Endo, 2017). Anterhynchium melanopterum is a rare species in Japan and is also found in South Korea and China (Yamane, 1990; Yamane \& Murota, 2015; Yamane \& Terayama, 2016). This species has never been recorded in our study area. Anterhynchium gibbifrons was described based on specimens obtained from central Japan (Yamane \& Murota, 2015) and initially considered as endemic (Murota $\&$ Yamane, 2015). However, multiple lines of evidence indicate that $A$. gibbifrons has recently been unintentionally introduced to Japan (Watanabe et al., 2020). Specifically, Ohkusa (2019) discovered a specimen of $A$. gibbifrons collected from South Korea in 1974, substantially predating the oldest specimen recorded in Japan, collected in 2007 (Endo, 2017). In addition, records of this species have been increasing across a wide area in southwestern Japan since 2015 (Ohkusa, 2015; Kawashima, 2016; Komeda, 2016; Nakamura, 2020; Watanabe et al., 2020; Ito et al., 2021), following the publication of the species description (Yamane \& Murota, 2015). Finally, at least four other bamboo-associated insects, Xylocopa tranquebarorum tranquebarorum (Swederus, 1787) (Hymenoptera: Apidae), Sinibotys butleri (South, 1901) (Lepidoptera: Crambidae), Platylomia pieli Kato, 1938 (Hemiptera: Cicadidae) and Hierodula sp. (Mantodea: Mantidae), have been unintentionally introduced to Japan via bamboo products (Okabe et al., 2010; Mano \& Takasaki, 2011; Hayashi \& Usui, 2017; Sakurai et al., 2018). Given that A. gibbifrons typically nests in dead bamboo canes (Murota \& Yamane, 2015; Endo, 2017), it is possible that it was introduced via bamboo products. An extensive trap nest survey was conducted in our study area in 2005, with no detections of $A$. gibbifrons (T. Endo \& Y. Nishimoto, unpubl. data). However, the species has been collected frequently in the area studied since 2011 (T. Endo \& N. Ijiri, unpubl. data). Thus, $A$. gibbifrons presumably invaded the study area during 2005-2011.

The cavity nesting behaviour of $A$. flavomarginatum and $A$. gibbifrons (Figs 2 and 3) is described by Iwata (1975) and Murota \& Yamane (2015), respectively. First, the female wasp lays an egg 

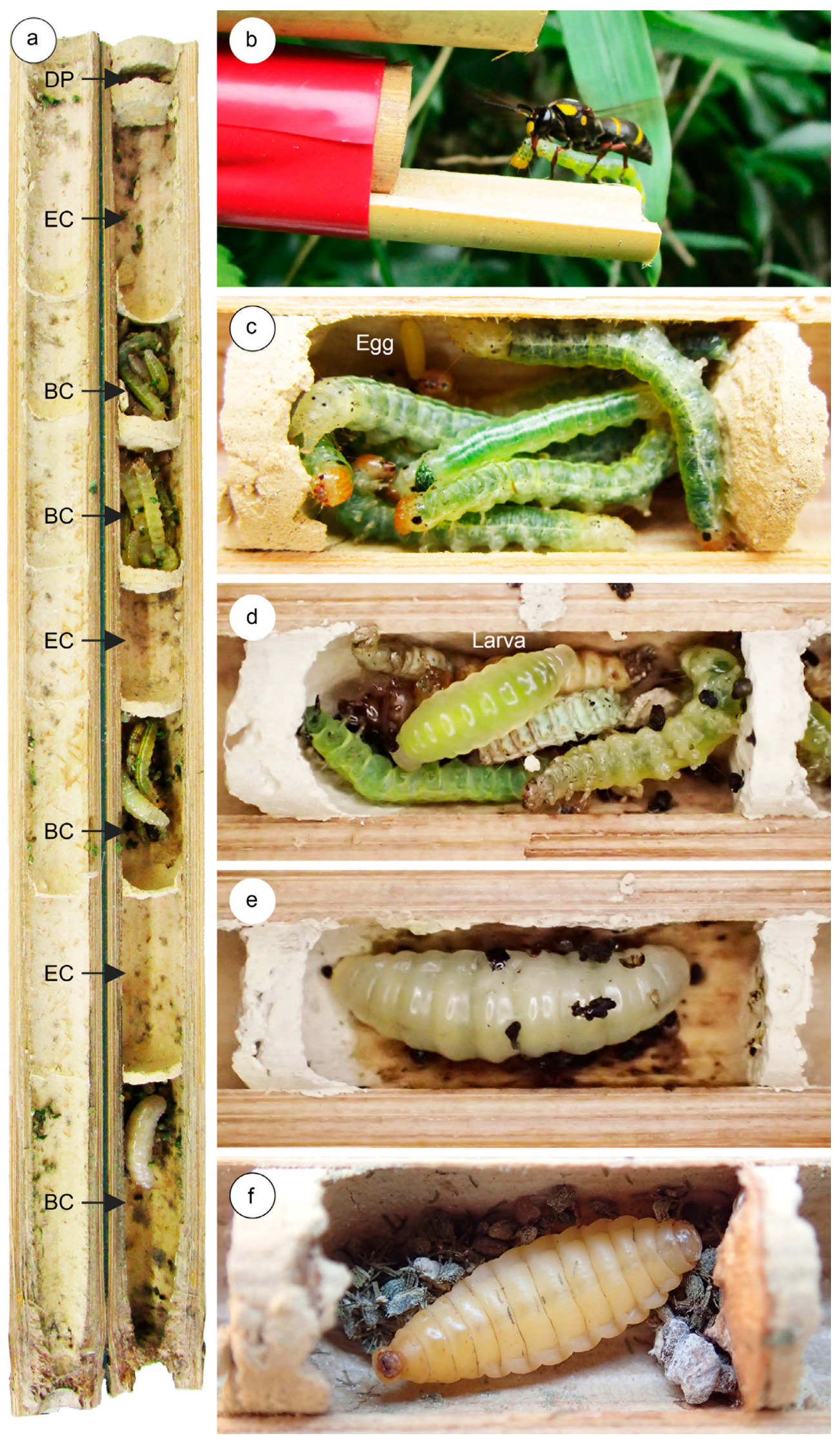

Fig. 2. The nests, developmental stages and prey of Anterhynchium flavomarginatum. (a) Representative architecture of a nest of $A$. flavomarginatum constructed in a bamboo cane (cross section). Bamboo canes were always placed horizontally in the trap boxes (see Fig. 1; this photograph is rotated through $90^{\circ}$ counter-clockwise). This nest is composed of four brood cells (BC) and three empty cells (EC). All cells are separated by mud walls and the cavity entrance is typically sealed with a double mud plug (DP). (b) An adult female wasp carrying a caterpillar into a bamboo cane. (c) An egg hanging from the ceiling of the brood cell and caterpillars provided by the mother wasp. (d) A middle instar wasp larva feeding on caterpillars in a brood cell. (e) A late-instar wasp larva in a brood cell. (f) A wasp prepupa in a brood cell. 

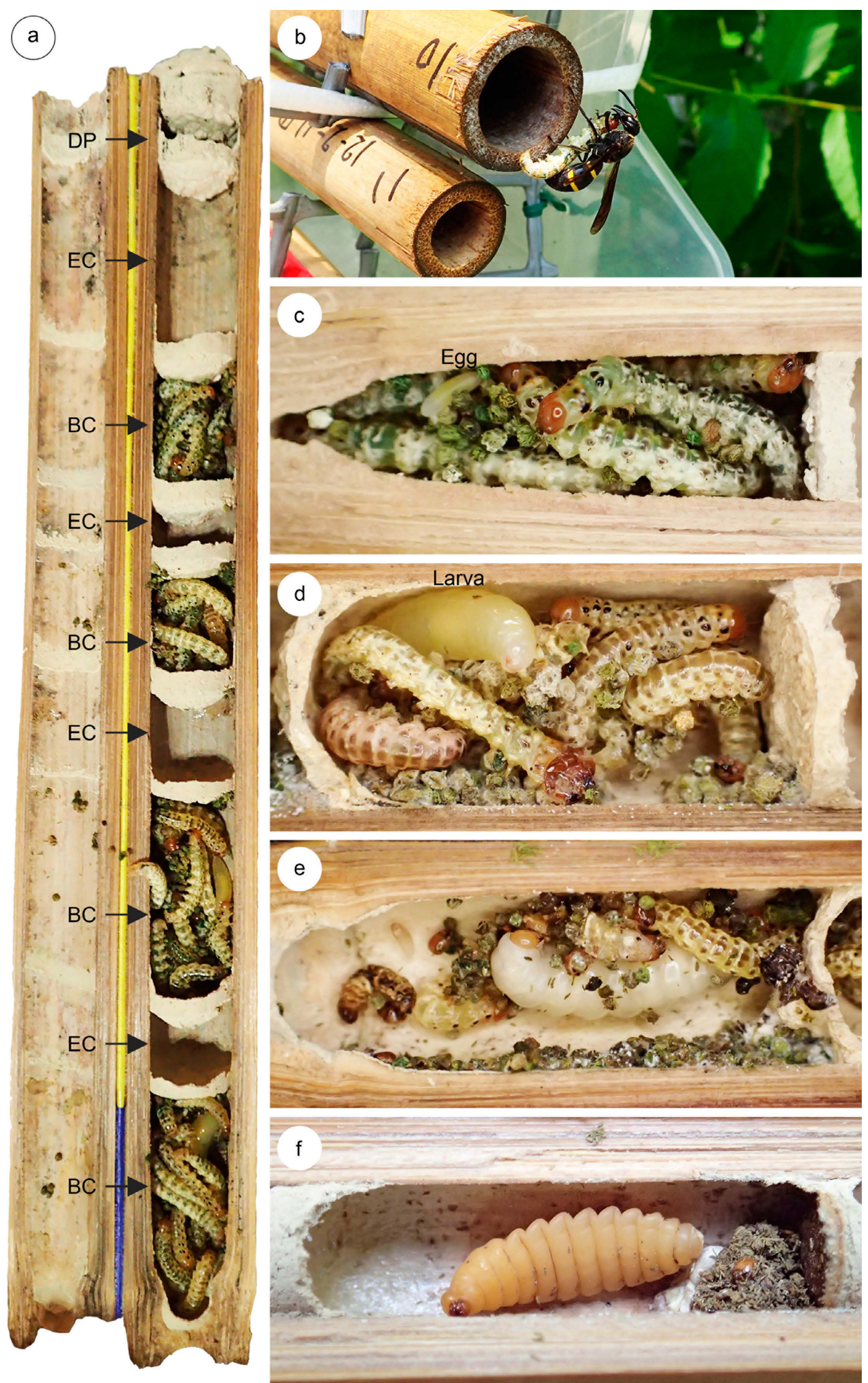

Fig. 3. The nests, developmental stages and prey of Anterhynchium gibbifrons. (a) Representative architecture of a nest of $A$. gibbifrons (cross section; see Fig. 2 for a description of cane orientation). This nest is composed of four brood cells (BC) and four empty cells (EC). All cells are separated by mud walls and the cavity entrance is typically sealed with a double mud plug (DP). (b) An adult female wasp carrying a caterpillar into a bamboo cane. (c) An egg hanging from the ceiling of a brood cell and caterpillars provided by the mother wasp. (d) A middle instar wasp larva feeding on caterpillars in a brood cell. (e) A late-instar wasp larva consuming prey in a brood cell. (f) A wasp prepupa in a brood cell. 
within a cavity, such as a tunnel created by wood-boring insects or a hollow plant stem (Iwata, 1975; Murota \& Yamane, 2015). Next, she hunts for lepidopteran larvae, permanently paralyzes them using her ovipositor and carries them to the cavity (Figs $2 b$ and 3b; Iwata, 1975; Murota \& Yamane, 2015). Once 3-21 larvae have been stored within the cavity, she seals the entrance using mud, at which point the cavity is referred to as a 'brood cell' (Fig. 2; Iwata, 1975). Female wasps typically create multiple brood cells separated by mud partitions (i.e., a nest; Figs $2 \mathrm{a}$ and $3 \mathrm{a}$; Iwata, 1975; Murota \& Yamane, 2015). Typically, intercalary and vestibular cells are also created, which are empty (Figs 2a and 3a; Krombein, 1967; Iwata, 1975; Murota \& Yamane, 2015). Eggs of both A. flavomarginatum and A. gibbifrons (Figs 2c and 3c) hatch within a few days and the larvae consume the stored lepidopteran larvae and grow rapidly (Figs $2 \mathrm{~d}, 2 \mathrm{e}, 3 \mathrm{~d}$ and $3 \mathrm{e}$ ). Although $A$. $\mathrm{fla}$ vomarginatum prey on the larvae of several species of leaf-rolling caterpillars (Lepidoptera: Crambidae, Pyralidae and Tortricidae; Iwata, 1975; Itino, 1992), the prey species of A. gibbifrons are unknown. Immature forms of both species are hosts for multiple parasitoid species (Coleoptera, Diptera and Hymenoptera; Iwata, 1975; Endo, 2017), but the percentage parasitism by both species has not been compared.

\section{Trap nests}

A total of 12 bamboo canes (four replicates of each for three inner diameter classes: $5-7,8-12$ and $13-16 \mathrm{~mm}$ ) were placed inside a plastic box (a 'trap box'; $250 \times 130 \times 330 \mathrm{~mm}$ ) to protect them from rain (Fig. 1; Tsujii, 2020). All trap nests (bamboo canes) were $200 \mathrm{~mm}$ in length, with one end open and the other closed at a node. Prior to placing the canes inside the trap boxes, each cane was split into two halves longitudinally and taped back together. This allowed easy examination of the contents of brood cells by simply opening the canes in the field. Each trap box was fixed to the trunk of a tree by string $1.5 \mathrm{~m}$ above the ground. In total, 48 trap boxes, each with 12 canes, were placed in a line along the forest edge at the study site on June 9 and 152019 , spaced at $10-\mathrm{m}$ intervals. No trap boxes were placed within $10 \mathrm{~m}$ of a residential area.

\section{Field surveys}

Traps were checked twice weekly from June to October 2019 (Tsujii, 2020). We first checked for the presence of insects or nests in each cane by probing with a thin grass stem. When canes were found to be occupied, they were opened to allow for insect identification. When canes were occupied by either species of $\mathrm{An}$ terhynchium, we photographed the nests using a digital camera (IXY210, Canon) and recorded the number of brood and empty cells, larval developmental stage and presence of parasitoids. Number of brood cells and developmental stages of larvae were only recorded once the cavity entrance had been sealed with mud or nesting activity had otherwise ceased. We also measured the fresh weight of the prey stored in the brood cells to the nearest $0.01 \mathrm{~g}$ using a portable electronic scale (MH-500, Zime). The weights of consumed prey, parasitoids and wasp larvae were not measured. In addition, we photographed prey for species identification. The lepidopteran and wasp larvae in each brood cell were counted.

Any ant colonies found within the trap nests were removed, as Anterhynchium are known to avoid ants (Miyano \& Yamaguchi, 2001). Once a cane was used for nesting by Anterhynchium or another species of cavity-nesting bee or wasp, a new cane of identical diameter was added to the box. Thus, nesting resources were kept constant over the period of the study. If nesting females were present upon trap box inspection, we waited until the insect had left to avoid disruption.

\section{Identification of wasps, prey and parasitoids}

Anterhynchium species were identified based on prepupal body colour; A. gibbifrons are more orange than A. flavomarginatum (Tsujii \& Endo, 2019). The sex of individuals of both species was determined based on the number of spots on the ventral abdomen of the prepupae; males have two spots on the 9th abdominal segment and females have a total of six spots (two each on the 7th, 8th and 9th segments; K. Gôukon, personal communication). Lepidopteran larvae were identified using field photographs. They were first sorted into morphological species based on external characters, including the size and colour of patterns on the head and body. They were then identified to the family, subfamily, genus or species level based on morphology, for example the presence of spots and number of spines (Solis, 2006; Yasuda, 2010; Komai et al., 2011; Yasuda, 2012; Passoa, 2014; Yasuda, 2014). Lepidopteran larvae on plants at the study site were also collected for comparison with the prey. Female moths were also collected at the study site and their larvae were reared from eggs obtained from females kept in the laboratory at $25^{\circ} \mathrm{C}$. Both collected and reared specimens were compared with the prey.

In addition, partial sequences of the mitochondrial COI gene were used to identify the prey of $A$. gibbifrons (i.e., DNA barcoding). DNA was extracted from prey $(n=6)$, a crambid species found on bamboo leaves at the study site $(\mathrm{n}=2)$ and an adult Demobotys pervulgalis (Hampson, 1913) (Lepidoptera: Crambidae) collected at the study site $(\mathrm{n}=1)$ and from a different location $(\mathrm{n}=1)$. Given that this species of moth was common at the study site, it was assumed to be the prey of $A$. gibbifrons. Whole larvae and a leg of adults were immersed in propylene glycol and stored at $4^{\circ} \mathrm{C}$ until subsequent DNA extraction. The methodology used for DNA extraction, PCR amplification and sequencing is described in Matsui et al. (2021). All obtained DNA sequences were deposited in the GenBank database (https://www.ncbi.nlm. nih.gov/genbank/: accession number: LC652646-LC652655). The scientific names of Crambidae species followed Nuss et al. (2021). Finally, parasitoids were identified to species level based on the morphology of larvae, pupae or adults (Kurahashi, 1970; Liu et al., 1995; Makino et al., 2006, 2011).

\section{Data analyses}

Generalised linear models (GLMs) with a Poisson error distribution and log link function were used to assess the relationships of wasp species and nesting period with nest architecture, specifically the number of brood and empty cells within a nest. Wasp species and nesting period were fixed effects, and the total number of cells and number of brood and empty cells were response variables. GLMs with a Gaussian error distribution and identity link were then used to assess relationships among species, nesting period and nest inner diameter. Wasp species and nesting period were fixed effects, and the inner diameter of the cane was used as the response variable. P-values were adjusted for multiple comparisons using the Benjamini-Hochberg procedure (Benjamini \& Hochberg, 1995) in emmeans (ver. 1.5.3) and multcomp (ver. 1.4.15) R packages.

Generalised linear mixed models (GLMMs) with a Poisson error distribution and log link function were used to assess relationships among species, nesting period, wasp sex and number of prey. Species, nesting period and sex were fixed effects and the number of prey larvae and species per brood cell were response variables. Individual bamboo canes were random effects. GLMMs with a Gaussian error distribution and identity link were then used to assess relationships between the same fixed effects and prey weight. GLMMs were constructed using the packages lme4 (ver. 1.1.26) and lmerTest (ver. 3.1.3). P-values were adjusted for multiple comparisons using the Benjamini-Hochberg pro- 


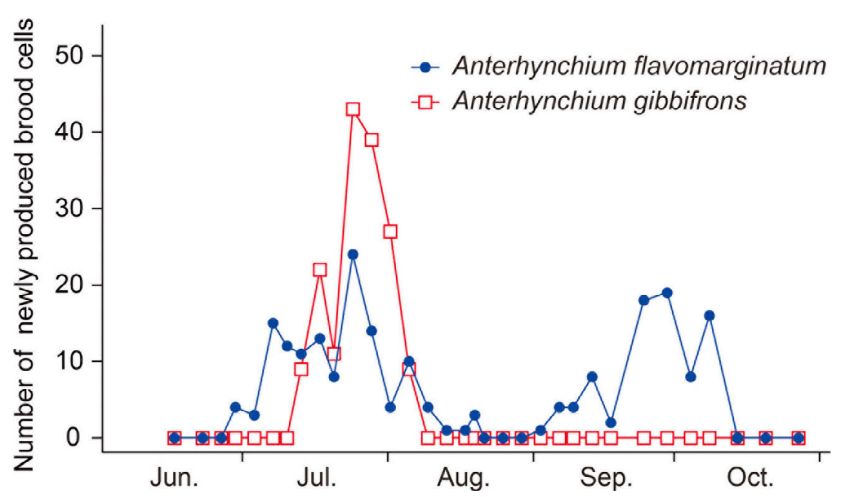

Fig. 4. Seasonal changes in the number of newly produced brood cells. Blue circles and red squares indicate Anterhynchium flavomarginatum and $A$. gibbifrons, respectively.

cedure (Benjamini \& Hochberg, 1995) in emmeans (ver. 1.5.3) and multcomp (ver. 1.4.15) R packages.

Fisher's exact tests were used to compare the percentage of brood cells of the two wasps attacked by parasitoids. P-values were adjusted for multiple comparisons using the BenjaminiHochberg procedure (Benjamini \& Hochberg, 1995). Binomial tests were also used to compare the observed wasp sex ratio (the proportion of males) with a $1: 1$ ratio.

All analyses were performed using R statistical analysis software (ver. 4.0.3; R Core Team, 2020).

\section{RESULTS}

\section{Seasonal patterns in nesting activity}

Of the 950 bamboo canes, $31.3 \%$ were used by cavitynesting bees (3 species) and wasps (10 species). Anterhynchium flavomarginatum nested in 70 canes (total of 207 brood cells) and A. gibbifrons nested in 50 canes (160 brood cells). Anterhynchium flavomarginatum produced two generations over the period of the study (first nesting period, late June-mid August, 127 brood cells in 48 nests; second nesting period, early September-early October, 80 cells in 22 nests; Fig. 4), whereas A. gibbifrons produced only one generation (nesting period, mid July-early August; Fig. 4). Although A. gibbifrons began nesting two weeks after $A$. flavomarginatum started, the nesting period of $A$. gibbifrons overlapped that of the first nesting period of A. flavomarginatum (Fig. 4). In A. flavomarginatum, $12.6 \%$ of the larvae (16 of 127 cells) produced during the first nesting period pupated and emerged during July-August 2019 , whereas $28.3 \%$ (36 of 127 cells) from the first nesting period overwintered as prepupae. The remaining larvae were killed by parasitoids or other factors. The larvae produced during the second nesting period overwin- tered as prepupae and emerged as adults in May-June 2020. In $A$. gibbifrons, no larvae pupated or emerged during July-August 2019, but overwintered as prepupae and adults emerged in May-June 2020. Therefore, A. flavomarginatum and $A$. gibbifrons showed partial bivoltinism and univoltinism, respectively.

The sex ratio (proportion of males) among the prepupae produced in the first and second nesting periods of $A$. $\mathrm{fla}$ vomarginatum was $0.87(\mathrm{n}=62)$ and $0.62(\mathrm{n}=60)$, respectively. The sex ratio in $A$. gibbifrons was $0.80(\mathrm{n}=103)$. The sex ratio in the first nesting period of $A$. flavomarginatum and $A$. gibbifrons was male-biased and significantly different from a $1: 1$ ratio (binomial tests, $\mathrm{p}<0.001$ ). The sex ratio in the second nesting period of A. flavomarginatum was not significantly different from the $1: 1$ ratio $(\mathrm{p}>$ 0.05).

\section{Nest architecture and prey}

There were no significant differences in the number of brood cells, empty cells or inner diameter of the canes used by the two species (Table 1). In both species, daughters (female offspring) were provisioned with a greater weight and number of prey than sons (male offspring) (Table 2). The diversity of prey species per brood cell did not differ significantly between species or sex, although the number of prey species was significantly different for sons in the first nesting period of $A$. flavomarginatum and sons of $A$. gibbifrons (Table 2).

Anterhynchium flavomarginatum collected the larvae of 14 species of moths (Lepidoptera: Crambidae, Pyralidae, Tortricidae) as prey for their larvae (Table 3). The prey composition of the first nesting period was different from that of the second nesting period; Circobotys sp. (Lepidoptera: Crambidae) were used exclusively in the first nesting period but not in the second nesting period (Table 3). Anterhynchium gibbifrons used the larvae of a single moth species in the family Crambidae (subfamily Pyraustinae). This species is morphologically identical to a crambid species that was observed rolling or tying bamboo leaves together at the study site. These larvae were morphologically identical to those reared from eggs obtained from female adults of Demobotys pervulgalis. Furthermore, a 562 base pair sequence of the COI obtained from $A$. gibbifrons prey in the nests was identical to the sequences obtained from the field-collected larvae (99.8-100.0\% matched) and $D$. pervulgalis adults (99.8-100.0\% matched). Therefore, $A$. gibbifrons exclusively used the larvae of $D$. pervulgalis as prey and did not share any prey species with $A$. flavomarginatum.

Table 1. The nest architecture of Anterhynchium flavomarginatum and $A$. gibbifrons. First - first nesting period; Second - second nesting period. $\mathrm{n}$ - the number of canes used by Anterhynchium wasps for nesting. ${ }^{*}-p<0.05$ (GLMs); $n$.s. $-p>0.05$ (GLMs). Different letters indicate significant differences between wasp species and generations (GLMs with the Benjamini-Hochberg procedure, $p<0.05$ ).

\begin{tabular}{|c|c|c|c|c|}
\hline & \multicolumn{2}{|c|}{ A. flavomarginatum } & \multirow{2}{*}{$\begin{array}{l}\text { A. gibbifrons } \\
(\mathrm{n}=50)\end{array}$} & \multirow{2}{*}{ Statistical test } \\
\hline & First $(n=48)$ & Second $(n=22)$ & & \\
\hline Total number of cells [median (range)] & $6(1-9)$ & $5(3-9)$ & $6(1-9)$ & n.s. \\
\hline Number of brood cells [median (range)] & $2(1-6)$ & $4(1-9)$ & $3(1-5)$ & n.s. \\
\hline Number of empty cells [median (range)] & $3(0-5) a$ & $2(0-3) b$ & $3(0-5) a$ & * \\
\hline Inner diameter of used canes [mean \pm SE] & $10.0 \pm 0.3$ & $9.5 \pm 0.4$ & $10.3 \pm 0.3$ & n.s. \\
\hline
\end{tabular}


Table 2. The total weight and number of prey per brood cell for Anterhynchium flavomarginatum and A. gibbifrons. $\mathrm{n}-$ the number of brood cells. The same letters indicate no significant difference (GLMMs, $p>0.05$ ). The total weight and number of prey were determined for brood cells containing wasp eggs and early instars. For such cells, data only on those for which the sex of the wasp offspring could be identified at the prepupal stage were used in the analyses.

\begin{tabular}{|c|c|c|c|c|c|c|}
\hline & \multicolumn{4}{|c|}{ A. flavomarginatum } & \multirow{2}{*}{\multicolumn{2}{|c|}{ A. gibbifrons }} \\
\hline & \multicolumn{2}{|c|}{ First nesting period } & \multicolumn{2}{|c|}{ Second nesting period } & & \\
\hline & $\begin{array}{l}\text { Daughter } \\
\quad(n=5)\end{array}$ & $\begin{array}{c}\text { Son } \\
(n=44)\end{array}$ & $\begin{array}{l}\text { Daughter } \\
(\mathrm{n}=22)\end{array}$ & $\begin{array}{c}\text { Son } \\
(n=30)\end{array}$ & $\begin{array}{l}\text { Daughter } \\
(\mathrm{n}=21)\end{array}$ & $\begin{array}{c}\text { Son } \\
(n=76)\end{array}$ \\
\hline Total weight of prey $(\mathrm{mg})[$ mean $\pm \mathrm{SE}]$ & $798.0 \pm 31.5 a b$ & $424.0 \pm 17.1 d$ & $745.7 \pm 23.5 b$ & $406.3 \pm 17.6 \mathrm{~d}$ & $880.8 \pm 42.4 \mathrm{a}$ & $595.4 \pm 19.8 c$ \\
\hline Number of prey [median (range)] & $12(8-15) p$ & $5.5(3-13) q$ & $10(6-19) p$ & $6(3-12) q$ & $11(6-15) p$ & $7(4-17) q$ \\
\hline Number of species of prey [median (range)] & $1(1-3) x y$ & $1(1-5) x$ & $1(1-3) x y$ & $1(1-3) x y$ & $1(1-1) x y$ & $1(1-1) y$ \\
\hline
\end{tabular}

\section{Parasitoids}

One coleopteran, three dipteran and one hymenopteran species parasitized the Anterhynchium wasps (Table 4). Larvae of Macrosiagon nasutum (Thunberg, 1784) (Coleoptera: Ripiphoridae) parasitized wasp prepupae. Larvae of Amobia distorta (Allen, 1926) (Diptera: Sarcophagidae) were found feeding on wasp larvae and larvae of Anthrax aygulus Fabricius, 1805 (Diptera: Bombyliidae) parasitized wasp prepupae. Adults and larvae of Megaselia sp. (Diptera: Phoridae) fed on wasp eggs and larvae, respectively. Larvae of Melittobia sp. (Hymenoptera: Eulophidae) parasitized wasp prepupae. Larvae of Amobia distorta and Megaselia sp. fed on moth larvae, as well as wasp larvae in brood cells. Among the six species, Amobia distorta was the most abundant (Table 4). Macrosiagon nasutum, Amobia distorta and Megaselia sp. attacked both A. flavomarginatum and A. gibbifrons (Table 4). The total percentage parasitism was higher in A. flavomarginatum than A. gibbifrons (Fisher's exact test, $\mathrm{p}<0.05$; Table 4). The percentage parasitism by Amobia distorta was also higher in A. flavomarginatum than A. gibbifrons ( $\mathrm{p}<0.05$ ), but those of M. nasutum and Megaselia sp. did not significantly differ between the two species ( $p>0.05$; Table 4$)$.

\section{DISCUSSION}

We compared resource use and natural enemies of a native and supposedly non-native species of Anterhynchium. We found overlap in nesting period between the two, similar nest architecture and inner cane diameter preference, but a completely independent use of prey. Therefore, $A$. gibbifrons potentially competes with $A$. flavomarginatum for nesting resources, but not prey, in the area studied. Three parasitoid species attacked both Anterhynchium species, suggesting that $A$. gibbifrons could indirectly affect $A$. flavomarginatum via shared parasitoids.

\section{Nest architecture and provision of prey}

Nests in terms of the inner diameter of the bamboo cane and number of brood and empty cells were similar for the two species. Although we ensured a constant and ample supply of nesting material at the study site, suitable natural nesting resources, such as wood cavities, are generally limited under natural conditions (Krombein, 1967). Therefore, it is reasonable to assume that these species may compete for nest sites under natural conditions.

Adult females are larger than males in both species $(A$. flavomarginatum body length: female, $15.0-20.5 \mathrm{~mm}$, male, $11.0-15.5 \mathrm{~mm}$; A. gibbifrons: female, $18-20 \mathrm{~mm}$,

Table 3. Prey species and composition for Anterhynchium flavomarginatum and A. gibbifrons. $\mathrm{n}$ - number of brood cells in which the prey were examined. * - indicates specimens that could not be identified. Data for prey consumed by wasps and parasitoids were excluded.

\begin{tabular}{|c|c|c|c|c|c|c|c|}
\hline \multirow{3}{*}{$\begin{array}{l}\text { Prey } \\
\text { Family }\end{array}$} & \multirow{3}{*}{ Species } & \multicolumn{4}{|c|}{ A. flavomarginatum } & \multirow{2}{*}{\multicolumn{2}{|c|}{$\begin{array}{c}\text { A. gibbifrons } \\
(n=153)\end{array}$}} \\
\hline & & \multicolumn{2}{|c|}{$\begin{array}{l}\text { First nesting period } \\
\qquad(\mathrm{n}=116)\end{array}$} & \multicolumn{2}{|c|}{$\begin{array}{l}\text { Second nesting period } \\
\qquad(\mathrm{n}=73)\end{array}$} & & \\
\hline & & $\begin{array}{l}\text { Number } \\
\text { of prey }\end{array}$ & $\begin{array}{l}\text { Number of } \\
\text { brood cells }\end{array}$ & $\begin{array}{l}\text { Number } \\
\text { of prey }\end{array}$ & $\begin{array}{l}\text { Number of } \\
\text { brood cells }\end{array}$ & $\begin{array}{l}\text { Number } \\
\text { of prey }\end{array}$ & $\begin{array}{l}\text { Number of } \\
\text { brood cells }\end{array}$ \\
\hline \multirow[t]{13}{*}{ Crambidae } & Anania vicinalis (South, 1901) & 1 & 1 & 0 & 0 & 0 & 0 \\
\hline & Circobotys sp. & 362 & 57 & 0 & 0 & 0 & 0 \\
\hline & Demobotys pervulgalis (Hampson, 1913) & 0 & 0 & 0 & 0 & 1264 & 153 \\
\hline & Diaphania indica (Saunders, 1851) & 0 & 0 & 13 & 8 & 0 & 0 \\
\hline & Haritalodes derogata (Fabricius, 1775) & 57 & 14 & 39 & 10 & 0 & 0 \\
\hline & Herpetogramma luctuosalis (Guenée, 1854) & 134 & 30 & 307 & 45 & 0 & 0 \\
\hline & Herpetogramma rudis (Warren, 1892) & 31 & 9 & 0 & 0 & 0 & 0 \\
\hline & Mecyna tricolor (Butler, 1879) & 92 & 20 & 0 & 0 & 0 & 0 \\
\hline & Palpita nigropunctalis (Bremer, 1864) & 9 & 6 & 74 & 19 & 0 & 0 \\
\hline & Pyrausta sp. & 8 & 2 & 0 & 0 & 0 & 0 \\
\hline & Spoladea recurvalis (Fabricius, 1775) & 63 & 12 & 153 & 14 & 0 & 0 \\
\hline & Pyraustinae sp. A & 49 & 13 & 10 & 2 & 0 & 0 \\
\hline & Pyraustinae unidentified spp.* & 2 & 1 & 0 & 0 & 0 & 0 \\
\hline Pyralidae & Phycitinae sp. & 9 & 2 & 0 & 0 & 0 & 0 \\
\hline \multirow[t]{2}{*}{ Tortricidae } & Tortricidae sp. A & 15 & 9 & 0 & 0 & 0 & 0 \\
\hline & Tortricidae sp. B & 1 & 1 & 0 & 0 & 0 & 0 \\
\hline
\end{tabular}


Table 4. Parasitoids of Anterhychium flavomarginatum and $A$. gibbifrons. First - first nesting period; Second - second nesting period. $\mathrm{n}$ - the number of brood cells. A - adult; $\mathrm{L}-$ larva; HE - host egg; HL - host larva; HPP - host prepupa; ML - moth larva. * $-\mathrm{p}<0.05$ (Fisher's exact tests); n.s. - p $>0.05$ (Fisher's exact tests). The same letters indicate no significant difference (Fisher's exact tests with the Benjamini-Hochberg procedure, $\mathrm{p}>0.05)$.

\begin{tabular}{|c|c|c|c|c|c|c|c|c|}
\hline \multicolumn{5}{|l|}{ Parasitoid } & \multicolumn{4}{|c|}{ Percentage parasitism (\%) } \\
\hline \multirow[b]{2}{*}{ Order } & \multirow[b]{2}{*}{ Family } & \multirow[b]{2}{*}{ Species } & \multirow[b]{2}{*}{ Stage } & \multirow[b]{2}{*}{ Food } & \multicolumn{2}{|c|}{ A. flavomarginatum } & \multirow{2}{*}{$\begin{array}{l}\text { A. gibbifrons } \\
(\mathrm{n}=160)\end{array}$} & \multirow{2}{*}{$\begin{array}{c}\text { Statistica } \\
\text { test }\end{array}$} \\
\hline & & & & & $\begin{array}{c}\text { First } \\
(n=127)\end{array}$ & $\begin{array}{l}\text { Second } \\
(n=80)\end{array}$ & & \\
\hline Coleoptera & Ripiphoridae & Macrosiagon nasutum (Thunberg, 1784) & $\mathrm{L}$ & HPP & 3.9 & 0 & 0.6 & n.s. \\
\hline \multirow[t]{3}{*}{ Diptera } & Sarcophagidae & Amobia distorta (Allen, 1926) & $\mathrm{L}$ & $\mathrm{HL}, \mathrm{ML}$ & $10.2 \mathrm{a}$ & $17.5 \mathrm{a}$ & $3.1 \mathrm{~b}$ & * \\
\hline & Bombyliidae & Anthrax aygulus Fabricius, 1805 & $\mathrm{~L}$ & HPP & 0.8 & 0 & 0 & n.s. \\
\hline & Phoridae & Megaselia sp. & $A / L$ & $\mathrm{HE}, \mathrm{HL}, \mathrm{ML}$ & 3.1 & 1.3 & 3.1 & n.s. \\
\hline Hymenoptera & Eulophidae & Melittobia sp. & $\mathrm{L}$ & HPP & $4.7 p$ & $0 \mathrm{pq}$ & $0 q$ & * \\
\hline Total & & & & & $22.8 x$ & $18.8 x$ & $6.9 \mathrm{y}$ & * \\
\hline
\end{tabular}

male, 14-19 mm; Yamane \& Terayama, 2016). Female offspring were provided with a greater amount of prey than male offspring by both species. Cowan (1991) suggests that the amount of prey provided is determined primarily by memory of the sex of the deposited egg in eumenine wasps. Like other eumenine species, A. flavomarginatum and $A$. gibbifrons may also adjust the amount of prey provided according to the sex of the offspring.

\section{Prey use}

Generally, most eumenine wasps are generalists; few are specialists (Krombein, 1967; Cowan, 1991). These wasps generally prey on the larvae of moths or beetles (Cowan, 1991). For example, many species of the genus Symmorphus Wesmael, 1836 prey on the larvae of several weevil and leaf beetle species (i.e., generalists; Gathmann \& Tscharntke, 1999; Budrienè, 2003), whereas Symmorphus decens (Kostylev, 1940) exclusively hunts the larvae of a single leaf beetle species (i.e., specialists; Hamanishi, 1996). Species in other genera, such as Ancistrocerus Wesmael, 1836 and Discoelius Latreille, 1809, typically prey on the larvae of several moth species (Itino, 1992; Harris, 1994; Dang \& Nguyen, 2019). We identified the larvae of 14 and 1 moth species as prey of $A$. flavomarginatum and $A$. gibbifrons, respectively. Larvae of the moth families Crambidae, Pyralidae and Tortricidae are reported as prey of A. flavomarginatum (Iwata, 1975; Itino, 1992). Although the prey of $A$. gibbifrons was unknown, our results indicate it is a specialist and that $A$. flavomarginatum is a generalist in the area studied.

The composition of prey A. flavomarginatum differed in the two nesting periods. This indicates that females use the most abundant prey during each nesting period. Although these females used the larvae of 14 species of moth as prey, they also showed a tendency to provide several larvae of only a few or one species within a single brood cell. Therefore, individuals of $A$. flavomarginatum may select for particular species, based on prey availability in order to increase foraging efficiency around nest sites. This type of specialist behaviour within a generalist species is reported in other wasp and bumblebee species (Heinrich, 1976; Cowan, 1991; Powell \& Taylor, 2017).

When two species share a potential resource, both or either species can shift their diet niche and so partition the resource (Begon et al., 2006; Kishi \& Tsubaki, 2014). For example, A. flavomarginatum may avoid the prey used exclusively by $A$. gibbifrons, and/or $A$. gibbifrons may have narrowed its range of prey use. However, given how recently $A$. gibbifrons is believed to have invaded the study site, it is unlikely that enough time has passed to drive a shift in diet between these two species. Rather, it seems more likely that $A$. gibbifrons simply utilizes prey that is not used by the native generalist species, i.e., it occupied an empty niche. To test if $A$. gibbifrons has indeed occupied an empty niche, further investigations are required in areas where $A$. gibbifrons does not co-occur with $A$. flavomarginatum; alternatively, the prey preferences of A. flavomarginatum and $A$. gibbifrons could be tested in a laboratory setting.

\section{Parasitoids}

Nine and four parasitoid species are reported parasitizing A. flavomarginatum and A. gibbifrons, respectively (Iwata, 1975; Itino, 1986; Yamane, 1990; Makino et al., 2006; Endo, 2017; Maeta \& Gôukon, 2019). Although the percentage parasitism of the former species is known (Itino, 1986), this is not the case for the latter species. Here, five and three species were found to parasitize these species, respectively. No species was found to exclusively attack $A$. gibbifrons. Because three parasitoid species (M. nasutum, Amobia distorta and Megaselia sp.) attacked both species at the study site, A. gibbifrons could indirectly affect the native $A$. flavomarginatum via shared parasitoids (i.e., apparent competition). For example, $A$. gibbifrons may have increased the population of Amobia distorta prior to the second nesting period of A. flavomarginatum, thereby contributing to the observed increase in parasitism between the first and second nesting periods (from $10.2 \%$ to $17.5 \%$ ). However, we note that the total percentage parasitism did not differ significantly between the first and second nesting periods of $A$. flavomarginatum. Therefore, any potential competition between these species via shared parasitoids may currently be relatively minor.

\section{CONCLUSIONS}

The solitary wasp A. gibbifrons may have been unintentionally introduced to Japan (Watanabe et al., 2020), although there is no strong evidence for such an introduction. 
The distribution of $A$. gibbifrons is increasing throughout Japan (Ohkusa, 2015; Kawashima, 2016; Komeda, 2016; Nakamura, 2020; Watanabe et al., 2020; Ito et al., 2021). We demonstrated exclusive use of bamboo-feeding caterpillars by $A$. gibbifrons in an area in central Japan. We note that the non-native bamboo $P$. edulis present at our study site has been spreading throughout Japan (Someya et al., 2010; Shinohara et al., 2014), which could be aiding the spread of $A$. gibbifrons. We found that $A$. gibbifrons may indirectly affect $A$. flavomarginatum via shared nesting resources and enemies, but there is no evidence of competition for prey resources in the area studied. It is possible that A. gibbifrons may further interfere with A. flavomarginatum via disrupting nesting or reproductive behaviour, but we did not consider these direct interactions in this study. Further field observations could provide a more holistic understanding of both direct and indirect interactions between these two species.

ACKNOWLEDGEMENTS. This study was partially supported by a grant from the School of Human Sciences at Kobe College. We thank N. Ijiri and Y. Nishimoto for providing information on $A$. gibbifrons. We thank K. Utaka and K. Okuda for providing access to the study location. We are grateful to K. Gôukon for assistance in sexing immature wasps and thank M. Shibata, A. Nobori, Y. Goto, A. Iwai, H. Mochizuki, Y. Mori and T. Yoshimura for their assistance with field work.

\section{REFERENCES}

Aguiar A.P., Deans A.R., Engel M.S., Forshage M., Huber J.T., Jennings J.T., Johnson N.F., Lelej A.S., Longino J.T., LoHRMANN V. ET AL. 2013: Order Hymenoptera. - Zootaxa 3703: $51-62$.

Beggs J.R., Brockerhoff E.G., Corley J.C., Kenis M., MasciocCHI M., Muller F., Rome Q. \& Villemant C. 2011: Ecological effects and management of invasive alien Vespidae. - BioControl 56: 505-526.

Begon M., Townsend C.R. \& Harper J.L. 2006: Ecology: From Individuals to Ecosystems, 4th ed. Blackwell, Malden, $750 \mathrm{pp}$.

Benjamini Y. \& Hochberg Y. 1995: Controlling the false discovery rate: a practical and powerful approach to multiple testing. - J. R. Statist. Soc. (B) 57: 289-300.

Brock R.E., Cini A. \& Sumner S. 2021: Ecosystem services provided by aculeate wasps. - Biol. Rev. 96: 1645-1675.

Budrienè A. 2003: Prey of Symmorphus wasps (Hymenoptera: Eumeninae) in Lithuania. - Acta Zool. Lituan. 13: 306-310.

CowAN D.P. 1991: The solitary and presocial Vespidae. In Ross K.G. \& Matthews R.W. (eds): The Social Biology of Wasps. Cornell University Press, NY, Ithaca, pp. 33-73.

DANG H.T. \& NGUYEN L.T.P. 2019: Nesting biology of the potter wasp Rhynchium brunneum brunneum (Fabricius, 1793) (Hymenoptera: Vespidae: Eumeninae) in North Vietnam. - J. Asia-Pac. Entomol. 22: 427-436.

David P., Thébault E., Anneville O., Duyck P.-F., Chapuis E. \& LoEuilLe N. 2017: Impacts of invasive species on food webs: a review of empirical data. - Adv. Ecol. Res. 56: 1-60.

Elton C.S. 1958: The Ecology of Invasions by Animals and Plants. Methuen, London, $181 \mathrm{pp}$.

ENDO T. 2017: Effectiveness of bamboo tube trap-nests in biodiversity monitoring: a case of rapidly expanding population of mason wasp, Anterhynchium gibbifrons (Hymenoptera: Eumenidae). - Yaseihukki 5: 3-8 [in Japanese].
Fateryga A.V., Protsenko Y.V. \& Zhidkov V.Y. 2014: Isodontia mexicana (Hymenoptera, Sphecidae), a new invasive wasp species in the fauna of Ukraine reared from trap-nests in the Crimea. - Vestn. Zool. 48: 185-188.

GAO Y. \& ReITZ S.R. 2017: Emerging themes in our understanding of species displacements. - Annu. Rev. Entomol. 62: 165-183.

Gathmann A. \& TscharntKe T. 1999: Landschafts-Bewertung mit Bienen und Wespen in Nisthilfen: Artenspektrum, Interaktionen und Bestimmungsschlüssel. - Natursch. Landschaftspfl. Baden-Württ. 73: 277-305.

Hamanishi Y. 1996: Cleptoparasitic life of the tachinid fly, Symmorphomyia katayamai Mesnil et Shima, in the nest of host wasps hunting the chrysomelid-larva prey. - Jpn. J. Entomol. 64: 843-860.

HARRIS A.C. 1994: Ancistrocerus gazella (Hymenoptera: Vespoidea: Eumenidae): a potentially useful biological control agent for leafrollers Planotortrix octo, P. excessana, Ctenopseustis obliquana, C. herana, and Epiphyas postvittana (Lepidoptera: Tortricidae) in New Zealand. - N. Z. J. Crop Hortic. Sci. 22: 235-238.

HAYASHI M. \& UsuI T. 2017: New record of an alien cicada, Platylomia pieli (Hemiptera: Cicadidae) from Japan. - Jpn. J. Syst. Entomol. 23: 101-102.

HeINRICH B. 1976: The foraging specializations of individual bumblebees. - Ecol. Monogr. 46: 105-128.

Holt R.D. \& Bonsall M.B. 2017: Apparent competition. Annu. Rev. Ecol. Evol. Syst. 48: 447-471.

ITINO T. 1986: Comparison of life tables between the solitary eumenid wasp Anterhynchium flavomarginatum and the subsocial eumenid wasp Orancistrocerus drewseni to evaluate the adaptive significance of maternal care. - Res. Popul. Ecol. 28: 185-199.

Itino T. 1992: Differential diet breadths and species coexistence in leafroller-hunting eumenid wasps. - Res. Popul. Ecol. 34: 203-211.

Ito R., Nishiya K., Aвe J. \& Komeda Y. 2021: First record of Anterhynchium gibbifrons Yamane \& Murota, 2015 (Hymenoptera: Vespidae: Eumeninae) from Fukuoka and Miyazaki Prefecture, and additional records from Gifu and Nara Prefecture, Japan. - Tsunekibachi 36: 71-74 [in Japanese].

IwaTA K. 1975: Field Notes of a Naturalist. Asahi-shimbunsya, Tokyo, 565 pp. [in Japanese].

KaWASHIMA I. 2016: A record of Anterhynchium gibbifrons from Kanagawa Prefecture. - Kanagawa-Chûhô 188: 61-62 [in Japanese].

Kenis M., Auger-Rozenberg M.-A., Roques A., Timms L., Péré C., Cock M.J.W., Settele J., Augustin S. \& Lopez-Vaamonde C. 2009: Ecological effects of invasive alien insects. - Biol. Invasions 11: 21-45.

KIsHi S. \& TsubaKi Y. 2014: Avoidance of reproductive interference causes resource partitioning in bean beetle females. Popul. Ecol. 56: 73-80.

Komai F., Yoshiyasu Y., Nasu Y. \& Saito T. (eds) 2011: A Guide to the Lepidoptera of Japan. Tokai University Press, Kanagawa, 1305 pp. [in Japanese].

Komeda Y. 2016: The first record of Anterhynchium gibbifrons from Kyushu. - Pulex 95: 698-699 [in Japanese].

Krombern K.V. 1967: Trap-nesting Wasps and Bees: Life Histories, Nests, and Associates. Smithsonian Press, Washington, D.C., 590 pp.

KuRAHASHI H. 1970: Studies on the calypterate muscoid flies from Japan VII. Revision of the subfamily Miltogramminae (Diptera, Sarcophagidae). — Kontyû 38: 93-116. 
Liu N., Nagatomi A. \& Evenhuis N.L. 1995: Genitalia of the Japanese species of Anthrax and Brachyanax (Diptera, Bombyliidae). - Zool. Sci. 12: 633-647.

Losey J.E. \& VAughan M. 2006: The economic value of ecological services provided by insects. - BioScience 56: 311-323.

Mack R.N., Simberloff D., Lonsdale W.M., Evans H., Clout M. \& BAZZAZ F.A. 2000: Biotic invasions: causes, epidemiology, global consequences, and control. - Ecol. Appl. 10: 689-710.

Maeta Y. \& GôuKon K. 2019: Feeding habits of a wasp fan beetle, Macrosiagon nasutum (Thunberg) (Coleoptera, Rhipiphoridae). - Bull. Hoshizaki Green Found. 22: 231-235 [in Japanese, English abstract].

Makino S., Sayama K., Okabe K. \& Abe W. 2006: Trap-Nesting Bees and Wasps of Japan. URL: https://db.ffpri.go.jp/BBee/en/ index.html (last accessed 17 Dec. 2021).

Makino S., Sayama K., Okabe K. \& Abe W. 2011: Image database of cavity-nesting wasps and bees in Japan. - Jpn. J. Entomol. (N.S.) 14: 28-31 [in Japanese, English abstract].

MANO T. \& TAKASAKI Y. 2011: A breeding record of Sinibotys butleri (South) (Crambidae) with description of its larva and pupa. - Yugato 204: 41-46 [in Japanese].

Matsui Y., NaKa H. \& JinBo U. 2021: DNA barcoding and morphology reveal a new cryptic species of Nagiella (Lepidoptera, Crambidae, Spilomelinae) from Japan. - ZooKeys 1023: 171-192.

Miyano S. \& Yamaguchi T. 2001: Ants reduce nest building activities of tube-nesting wasps and bees (Hymenoptera). - Entomol. Sci. 4: 243-246.

Murota T. \& Yamane S. 2015: Notes on Anterhynchium gibbifrons Yamane et Murota recently found from Japan. - Tsunekibachi 27: 3-15 [in Japanese].

NAKAmuRA T. 2020: The first record of Anterhynchium gibbifrons Yamane et Murota, 2015 from Yamaguchi Prefecture. Tsunekibachi 35: 38 [in Japanese].

Nuss M., Landry B., Mally R., Vegliante F., TränKner A., Bauer F., Hayden J., Segerer A., Schouten R., Li H. et al. 2021: Global Information System on Pyraloidea. URL: http:// www.pyraloidea.org/ (last accessed 17 Dec. 2021).

Ohкusa S. 2015: On the distribution record of Anterhynchium gibbifrons. - Tsunekibachi 27: 1-2 [in Japanese].

OHKUSA S. 2019: On the distribution record of Anterhynchium gibbifrons Yamane et Murota, 2015 from Korea. - Tsunekibachi 34: 23-24 [in Japanese].

Okabe K., Masuya H., Kawazoe K. \& Makino S. 2010: Invasion pathway and potential risks of a bamboo-nesting carpenter bee, Xylocopa tranquebarorum (Hymenoptera: Apidae), and its micro-associated mite introduced into Japan. - Appl. Entomol. Zool. 45: 329-337.

PAssoA S.C. 2014: Key to frequently named lepidopteran larvae intercepted, or potentially encountered, at US ports. In Gilligan T.M. \& Passoa S.C. (eds): LepIntercept, an Identification Resource for Intercepted Lepidoptera Larvae. Identification Technology Program (ITP). USDA/APHIS/PPQ/S\&T. URL: https://idtools.org/id/leps/lepintercept/key.html (last accessed 17 Dec. 2021).

Peters R.S., Krogmann L., Mayer C., Donath A., Gunkel S., Meusemann K., Kozlov A., Podsiadlowski L., Petersen M., LANFEAR R. ET AL. 2017: Evolutionary history of the Hymenoptera. - Curr. Biol. 27: 1013-1018.

Powell E.C. \& TAYLOR L.A. 2017: Specialists and generalists coexist within a population of spider-hunting mud dauber wasps. - Behav. Ecol. 28: 890-898.

R CoRe TeAm 2020: $R$ : A Language and Environment for Statistical Computing. R Foundation for Statistical Computing. URL: https://www.r-project.org/ (last accessed 23 Mar. 2021).
Ravoet J., Barbier Y. \& KLeIN W. 2017: First observation of another invasive mud dauber wasp in Belgium: Sceliphron caementarium (Drury, 1773) (Hymenoptera: Sphecidae). - Bull. Soc. Roy. Belge Entomol. 153: 40-42.

Reitz S.R. \& Trumble J.T. 2002: Competitive displacement among insects and arachnids. - Annu. Rev. Entomol. 47: 435-465.

Sakurai H., Karube H. \& Kaga R. 2018: A case study of an unintentional introduction of the alien mantis Hierodula sp. - Egg cases adhering to bamboo brooms imported from China. Bull. Kanagawa Prefect. Mus. (Nat. Sci.) 47: 67-71 [in Japanese, English abstract].

Shinohara Y., Kume T., Ichinashi R., Komatsu H. \& Otsuki K. 2014: Moso-bamboo forests in Japan: what are the effects of their area expansion on ecosystem services? - J. Jpn. For. Soc. 96: 351-361 [in Japanese, English abstract].

SNYDER W.E. \& Evans E.W. 2006: Ecological effects of invasive arthropod generalist predators. - Annu. Rev. Ecol. Evol. Syst. 37: $95-122$.

Solis M.A. 2006: Key to selected Pyraloidea (Lepidoptera) larvae intercepted at U.S. ports of entry: revision of Pyraloidea in "Keys to some frequently intercepted Lepidopterous larvae" by Weisman 1986. URL: https://digitalcommons.unl.edu/systentomologyusda/1/ (last accessed 17 Dec. 2021).

Someya T., Takemura S., Miyamoto S. \& Kamada M. 2010: Predictions of bamboo forest distribution and associated environmental factors using natural environmental information GIS and digital national land information in Japan. - Landscape Ecol. Manag. 15: 41-54 [in Japanese, English abstract].

Staab M., Pufal G., Tscharntke T. \& Klein A.-M. 2018: Trap nests for bees and wasps to analyse trophic interactions in changing environments - A systematic overview and user guide. - Methods Ecol. Evol. 9: 2226-2239.

SUGIURA S. 2010: Species interactions-area relationships: biological invasions and network structure in relation to island area. - Proc. R. Soc. (B) 277: 1807-1815.

SUGIURA S. 2016: Impacts of introduced species on the biota of an oceanic archipelago: the relative importance of competitive and trophic interactions. - Ecol. Res. 31: 155-164.

Thomson D. 2004: Competitive interactions between the invasive European honey bee and native bumble bees. - Ecology 85: 458-470.

TsuJII M. 2020: An ecological study of interactions between two eumenine wasp species: master thesis summary. - Hum. Sci. 23: 26-30 [in Japanese].

TsUJII M. \& ENDO T. 2019: Identification method for two species of the genus Anterhynchium (Eumenidae, Hymenoptera) using body color of prepupa. - Hum. Sci. 22: 11-16 [in Japanese, English abstract].

Tylianakis J.M., TscharntKe T. \& Lewis O.T. 2007: Habitat modification alters the structure of tropical host-parasitoid food webs. - Nature 445: 202-205.

Watanabe K., Kawashima I. \& Seki E. 2020: Hymenopterous insects collected in a survey at Nihon Minka-en (the Japan Openair Folk House Museum, Kawasaki). - Bull. Kanagawa Pref. Mus. (Nat. Sci.) 49: 119-143 [in Japanese].

YAMANE S. 1990: A revision of the Japanese Eumenidae (Hymenoptera, Vespoidea). - Insecta Matsumurana N.S. 43: 1-189.

YAmANE S. \& Murota T. 2015: A new Anterhynchium species from Japan, with a key to the Northeast Asian species of the genus (Hymenoptera, Eumenidae). - Halteres 6: 95-103.

Yamane S. \& Terayama M. 2016: Eumeninae. In Terayama M. \& Suda H. (eds): A Guide to the Aculeate Wasps of Japan. Tokai University Press, Kanagawa, pp. 290-319 [in Japanese]. 
Yasuda M. 2010: The Handbook of Japanese Caterpillar. Bunichi Sogo Shuppan, Tokyo, 100 pp. [in Japanese].

Yasuda M. 2012: The Handbook of Japanese Caterpillar. Vol. 2. Bun-ichi Sogo Shuppan, Tokyo, 100 pp. [in Japanese].
YASUDA M. 2014: The Handbook of Japanese Caterpillar. Vol. 3. Bun-ichi Sogo Shuppan, Tokyo, 108 pp. [in Japanese].

Received October 26, 2021; revised and accepted January 7, 2022 Published online February 14, 2022 